REVISTA DE DERECHO UNED, núm. 1, 2006

\title{
MATRIMONIO Y DERECHO EN LA NOVELA EJEMPLAR DE CERVANTES «LA ESPAÑOLA INGLESA»
}

ENRIQUE VIVÓ DE UNDABARRENA

Sumario: I. INTRODUCCIÓN: A. APRECIACIÓN: a. Crítica negativa.-b. Nueva estima.-B. FECHAS: a. Saqueo de Cádiz.-b. Datación de la composición.-C. HUELLAS AUTOBIOGRÁFICAS E HISTORICAS: a. Recuerdos cervantinos.-b. Sevilla, y el convento de Santa Paula.-II. DESARROLLO: A. PRIMERA PARTE. LONDRES: a. La niña raptada en el saqueo de Cádiz.-b. En la casa del católico Clotaldo.- c.Isabela y Ricaredo.-d. En vísperas de la boda.-e. En el palacio de la Reina.-f. Al servicio de su Majestad.-B. SEGUNDA PARTE. AVENTURAS CORSARIAS: a. Galeras turcas con botín de una nave portuguesa.-b. Liberados los padres de Isabela.-C. TERCERA PARTE. EN TORNO A LA REINA: a. Ricaredo ofrece su presa y solicita su premio.-b. Anagnórisis en clave moderna.-c. El conde Arnesto desafía a Ricaredo.-d. La madre de Arnesto envenena a Isabela.-e. Isabela con fealdad monstruosa se desposa.-f. Marcha y espera de Isabela y sus padres.-D. CUARTA PARTE. EN SEVILLA: a. Cádiz y Sevilla.-b. Junto al convento de la monja de voz única.-c. La falsa noticia de la muerte de Ricaredo.-d. El voto de entrar monja.-e. Detenida a la puerta del monasterio.-E. EXCURSUS. RICAREDO RELATA SUS PERIPECIAS: a. Visita a Roma y adhesión católica.-b. Arnesto intenta dar muerte a Ricaredo.-c. Cautivo y llevado a Argel.-d. Redimido llega a Valencia y Sevilla.-F. EPÍLOGO.-b. La trascripción de los hechos.-c. La boda y la ejemplaridad moral.-III. COMENTARIO E INTERPRETACIÓN: A. UNA DOBLE REDACCIÓN: a. La desconexión del suceso histórico.-b. El rapto se superpone al núcleo central.-B. PARALELISMO CON OTRAS NOVELAS: a. «El amante liberal».-b. "Persiles y Sigismunda».-c. Una historia sefardí.C. SIGNIFICADO: a. El amor une a España e Inglaterra.-b. De la be- 
lleza corpórea a la del espíritu.-c. La afirmación católica.-IV. CONCLUSIONES: A. CONSIDERACIONES MATRIMONIALES: a. El matrimonio premio final.-b. El noviazgo como peregrinación amorosa.-c. La libertad para contraer matrimonio.-d. La promesa de matrimonio y voto de entrar en religión.-B. CONSIDERACIONES JURÍDICO MERCANTILES: a. Profusas referencias bancarias.-b. Razón de tan abundantes datos.

\section{PRENOTANDOS}

\section{A. APRECIACIÓN}

Los juicios literarios sobre la novela no han podido ser más contradictorios en la estimación de su mérito literario.

\section{a. Crítica negativa}

1. La consideración peyorativa culmina con Schevill y Bonilla, que consideran que la novela no pasa de ser una «solemne niñería».

Schevill como otros críticos anglosajones señala que la sociedad inglesa y sus costumbres eran en absoluto desconocidas a Cervantes, debido a que no tuvo ocasión de tratar en España con gentes inglesas a causa de hallarse en guerra lo que inevitablemente tuvo que traducirse en falta de color local, hasta dar en lo arbitrario. Se muestra en lo impropio de los nombres mismos de los personajes ingleses, ninguno de los cuales se hubiera llamado allí ni Ricaredo ni Clotaldo; y aun en errores de bulto como el dar por viva a la reina Isabel de Inglaterra en 1611 cuando había muerto ocho años antes.

2. Tampoco es favorable para ella Savj-Lopez que al incluir a $L a$ española inglesa en el grupo de las novelas de aventuras, extiende a ésta los defectos comunes a todas las de este tipo. Aquí, dice, ni los caracteres ni las costumbres sino las peripecias exteriores ocupan la narración: Un embrollo dramático.

Sin embargo decimos que este tipo de crítica no considera que en los tiempos en que Cervantes escribe sus novelas, lo normal y corriente era precisamente lo extraordinario y fabuloso.

3. Icaza dice a propósito de esta novela, que no habría estado de más a Cervantes, conocer algo de las costumbres palatinas antes de 
describir la corte de Inglaterra. Para él, la Reina de La española inglesa tiene el encanto de los reyes de los cuentos infantiles cuando espera en los corredores de palacio la nueva de sus navíos corsarios.

Según el mismo autor Cervantes al componer con diversos elementos, unos reales y otros imaginados las figuras de esta obra, no puso mientes en el modelo vivo: Ni Isabela, ni Ricaredo, ni el conde Arnesto, son personas de carne y hueso como otras creadas por Cervantes; parecen denunciar que cuando Cervantes no copiaba directamente del natural, perdía mucho de su personalidad artística.

Pero en compensación para Icaza, a ninguno de sus personajes vistió Cervantes con tanto esmero realista, como a los héroes imaginarios de La española e inglesa. Si habla de Isabela dice que llevaba saya entera de raso verde acuchillada, y con abanico a modo de las señoras damas españolas; si pinta a Ricaredo lo retrata con peto, espaldar, gola, brazaletes y escarcelas, con unas armas milanesas y sombrero de gran falda!.

Yendo más allá, Icaza cree que esta novela debió de ser improvisada, pues de otro modo no se explicarían los descuidos de estilo y las contradicciones.

4. En esta misma falta de aprecio coincide Amezúa, para quien al estilo de la Novela le falta a veces la sobriedad, la llaneza proverbial cervantina, para hacerse enfático e hinchado. Asimismo considera que tampoco tienen en ella explicación verosímil los aplazamiento de la boda, puro pretexto para prolongar la Novela. Todo ello apoyaría su creencia de que La española inglesa pudo ser una de sus primeras Novelas en su composición.

Por otra parte para llegar a la tolerancia política y religiosa que preside toda la novela, hay que deshumanizar un tanto sus personajes, empobrecer los caracteres.

Finalmente los descuidos y contradicciones no son pocos: los cómputos cronológicos erróneos del saco de Cádiz; la excesiva generosidad de Ricaredo con los cautivos algo inverosímil en corsarios en las costumbres del tiempo. El que la Reina inglesa tan pronto hable en lengua castellana como mediante un intérprete; la reina Isabel tenía bien sentada fama de políglota pero es cosa muy distinta que Cervantes le adjudique el conocimiento del español en un momento y se lo niegue en otro ${ }^{2}$.

1 F. DE ICAZA, Obras, I, México 1980, pág. 285.

2 A. G. DE AMEZUA, Cervantes creador de la novela corta española, II, Madrid 1982, pág. 147 . 


\section{b. Nueva estima}

1. De contrario parecer son los críticos como Pfandl para quien entre todas las novelas cervantinas La española inglesa es la mejor recibida por la crítica moderna; entre las Novelas ejemplares es la imaginada con mayor esmero y la más artística, embellecida con circunstancias que van alargando la acción.

2. Casalduero destaca en esta novela, cómo Cervantes, fiel a sus ideas, al despojar de su hermosura a Isabela, nos hace pasar de la belleza corpórea a la belleza del espíritu; dos valores humanos por los que Cervantes sentía una especial predilección.

Son los estudios sobre todo de Casalduero y de Lapesa como tendremos ocasión de apreciar, los que romperán definitivamente con las cortas perspectivas e inaugurarán la compresión literaria.

Para Avalle Arce, la estructura novelística, en que se dispone $L a$ española inglesa es una pequeña maravilla de sabiduría constructiva ${ }^{3}$.

\section{A. FECHAS}

La mención del saqueo de Cádiz al comienzo mismo de la novela impone como primera cuestión la de la cronología de la Novela.

\section{a. El saqueo de Cádiz}

1. La novela comienza con el saqueo de Cádiz por los ingleses. Una escuadra anglo-holandesa se apoderó de Cádiz en 1596 y saqueó la ciudad, llevándose un botín calculado en veinte millones de ducados.

No obstante, se produce confusión con otro anterior acaecido en 1587. Cervantes ya se había sentido entonces atraído en un célebre soneto sobre el mismo tema.

Ahora en la novela confunde el nombre del general Essex de las tropas inglesas de tierra llamándole Leste, pensando quizá en el conde de Leicester famoso por sus ataques a España que había muerto en $1588^{4}$.

${ }^{3}$ J. B. AVALLE-ARCE, Novelas Ejemplares, II, Madrid 1982, pág. 15. XXI.

4 SEVILLA Y REY, Miguel de Cervantes. Obra completa, VIII, Madrid 1996, pág. 
Aparte de esta confusión, todos los demás datos encajan perfectamente. El ataque a Cádiz fue necesariamente el de 1596, porque sólo en él hubo saqueo de la ciudad, como dice el texto; no pudo ser el de 1587 que se limitó a destruir la flota, pero no realizó desembarco alguno en la ciudad andaluza ${ }^{5}$.

2. Fernández de Navarrete nos detallaba el relato:

Todavía continuaba Cervantes su residencia en Sevilla en el año de 1596, cuando el 1 de julio entró en Cádiz una escuadra inglesa de 150 velas, mandada por el conde Carlos Howard, gran almirante de aquel reino, con un ejército de 23.000 hombres a las órdenes del conde de Essex, célebre valido de la reina Isabel de Inglaterra. Saqueáronla completamente y ricos con los tesoros que de ella sacaron, la incendiaron y abandonaron a los veinticuatro días ${ }^{6}$.

\section{b. Sobre la fecha de composición}

1. Hay un pasaje en la Novela que no sólo puede ayudarnos a conjeturar con más o menos probabilidad la fecha, sino que además plantea otros problemas de interés. Cuando al final de la novela, acaba el relato y se hacen presentes el Vicario y el Provisor del Arzobispo de Sevilla, el Asistente y otros principales caballeros, agrega Cervantes que los dos señores eclesiásticos rogaron a Isabela que pusiese toda aquella historia por escrito para que la leyese su señor Arzobispo y ella lo prometió.

Asensio después de copiar este párrafo dice a continuación: Leyendo este final se recuerda involuntariamente al licenciado Porras de la Cámara y su Miscelánea escrita para lectura del Arzobispo. La extraña petición - nada corriente para una mujer- de que Isabel pusiese por escrito su propia historia con destino al Prelado, lo explicaría.

Y la relación o entronque entre La española inglesa y el Códice de Porras entrevista por Asensio, la ha sostenido posteriormente un cervantista de la ponderación y talla de Rodríguez Marín, quien aporta muchos y valiosos datos para explicar las relaciones amistosas que hubo de haber entre Cervantes y el licenciado Porras durante las estancias sevillanas de éste?

5 Ibidem, pág. XXIV.

6 MARTÍN FERNÁNDEZ DE NAVARRETE, Vida de Miguel de Cervantes Saavedra. Madrid 1819 , pág. 85.

7 G. AMEZUA, loc. cit. pág. 129. 
Ciertamente que La española inglesa pudo ser escrita al tiempo de Rinconete y El celoso extremeño y servir de solaz al prelado sevillano, lo que no es cosa a la verdad disparatada. Ello la pondría en los últimos años del siglo Xvi o comienzos del Xviı al igual que las otras dos novelas del Códice de Porres.

Y sin embargo se plantea la duda, porque si Cervantes escribió la Novela de propósito para Porras y a petición de éste, ¿por qué el Racionero sevillano no la incluyó en su Códice?

2. Para Amezua la composición de La española inglesa hay que buscarla por diferente camino fundándola en otras consideraciones y matices, por ejemplo en el estilo de La española inglesa no puede ser una de las últimas novelas compuestas por el autor hacia 1611, pues se asemeja según la misma, por el estilo al primer Quijote, así que propone para su composición la fecha de 1604 a 1606, más próxima por lo tanto a la afrentosa toma de Cádiz que tanto había impresionado las imaginaciones contemporáneas; fundados en esta analogía cabría conjeturar la fecha de su composición hacia 1604-1606, aun cuando la indudable revisión en el estilo de la primera redacción de sus novelas, Cervantes hubo de hacerla antes de darlas a la imprenta en $1612^{8}$. Nada tendría de extraño que Cervantes hubiera modificado la primitiva redacción de su novela para publicarla en el volumen de Las ejemplares como hizo con Rinconete y El celoso extremeño9.

3. Icaza por su parte estima que es posterior al año 1605 en que fueron ratificadas con Inglaterra, por el conde de Nottinghan en nombre de Jacobo I de Inglaterra las paces ajustadas en Londres ${ }^{10}$. Durante la guerra nadie y menos Cervantes, que tenía muy viva la consternación que produjo en Andalucía el saqueo de Cádiz, podría haberse atrevido a hablar bien del conde y de la bondad de la reina de Inglaterra.

Según Pellicer La española inglesa se escribió en 1611 pues el saco de Cádiz ocurrió en 1596. A mediados de 1612 tenía Cervantes escritas todas sus novelas y pendientes tan sólo de aprobación.

Astrana Marín opina que La española inglesa se compuso en Madrid hacia 1611, puesto que de los ingleses no se podía escribir en los términos encomiásticos en que Cervantes lo realiza, sino después de la referida firma con Inglaterra ${ }^{11}$.

8 Ibidem, pág. 126.

9 SEVILLA Y REY, loc. cit. pág. XXIV.

10 F. DE ICAZA, loc. cit. pág. 287.

11 ASTRANA MARÍN, Vida ejemplar y heroica de Miguel de Cervantes Saavedra, V, Madrid 1953, pág. 202 ss. 
Para este biógrafo de Cervantes al que se critica de no hilar muy fino La española inglesa se escribió aprisa desde abril a junio; lo cierto es que quedan en el cuerpo de La española inglesa algunas muestras de una redacción apresurada, o de poco castigo en la corrección.

4. Según Rafael Lapesa la novela podría haberse escrito a partir de 1605 ó 1606; sin embargo se inclina por una fecha posterior. Calculó y aceptó el periodo 1609-1611 para la composición de La española inglesa, colocándose como en uno de los últimos jalones para la redacción definitiva en 1611. Sus aproximaciones argumentales e ideológicas a Persiles, hacen suponer que las fechas de redacción de ambas novelas serían relativamente próximas ${ }^{12}$.

Dice Rafael Lapesa, que Cervantes no buscó datos en libros ni archivos, sino en las huellas grabadas en su propia memoria. Precisamente las inexactitudes históricas obligan a suponer que los hechos no estaban recientes. Cervantes los veía a distancia confundiendo nombres y circunstancias no esenciales. Y esa lejanía conviene perfectamente a los años 1609 a 1611, reclamados también por la esperanzada visión de una Inglaterra tolerante ${ }^{13}$.

Rafael Lapesa ha intentado explicar esta actitud generosa de Cervantes para Inglaterra por la esperanza que hubo entonces en España de que esta nación volviese pronto al catolicismo ${ }^{14}$.

5. Cervantes residió en Andalucía desde 1587 hasta 1603.

Si Cervantes escribe entonces la novela, desde luego la retocó y modificó después, porque la visión que ofrece de Inglaterra y de su Reina es muy tolerante y demasiado comprensiva con los ingleses como para ser de aquel tiempo. El presentar a Isabel de Inglaterra sin tintas odiosas, sólo pudo ocurrir cuando desde su muerte (1603) mediase una distancia temporal bastante grande para que los rencores se hubiesen aplacado. Tampoco debían de estar muy inmediatas las medidas que Jacobo I adoptó contra los católicos en los primeros años de su reinado, en especial las que siguieron a la Conjuración de la pólvora en 1605.

Todo nos lleva a pensar que la novela cervantina fue compuesta cuando la impresión de tales acontecimientos se habían disipado y

12 R. LAPESA, En torno a La española inglesa y el Persiles. Homenaje a Cervantes, Valencia 1950, pág. 367

13 Ibidem, pág. 254, n. 19

14 G. AMEZUA, loc. cit. pág. 131 ss. 
parecía que la política de acercamiento iba a dar frutos como la fundación del «Colegio de Ingleses» en Valladolid; por lo tanto hacia 1609-1611, cuando el ambiente diplomático acentuaba el giro que conduciría poco después a la gestión del conde de Gondomar ministro de Felipe III y el rey inglés a las negociaciones para casar a su heredero Carlos con una infanta española ${ }^{15}$.

\section{B. HUELLAS AUTOBIOGRÁFICAS E HISTÓRICAS}

El método de encontrar modelos vivos al que tan aficionados fueron los cervantistas de los siglos pasados, encontró razones especiales en esta Novela.

Particularidad de ella es la abundancia de huellas y recuerdos. Blanca de los Ríos pudo escribir que La española inglesa era otra página autobiográfica de Cervantes. Lo ha mostrado Rafael la Pesa.

\section{a. Recuerdos cervantinos}

1. De todos, el más interesante para su biografía es el señalamiento del paraje marítimo en el que el bajel en que navegaba Ricaredo es apresado por galeotas turcas, que circunscribe diciendo que era el llamado de Las Tres Marías en la costa de Francia. Cervantes al precisar este punto del golfo de Lyon, trajo a la novela la evocación exacta de aquel en que la galera Sol donde Cervantes iba de Italia a España fue tomada por las galeras turcas de Arnaute Mami, comenzando entonces su penoso cautiverio al igual que el protagonista de este relato. Tan grabado tenía él en su memoria este desdichado suceso.

2. Pero no es éste rastro autobiográfico el único de La española inglesa, otros no menos vivos se encuentran en ella. Que el novelista revista su ficción con sus propias vivencias, no puede extrañar a nadie siendo en la cautividad en Argelia donde principalmente entran esos retazos autobiográficos que adquieren mayor vividez al estar presentados en primera persona en el relato de Ricaredo. Lo mismo ocurre con la historia del capitán cautivo que también se narra en primera persona.

15 RAFAEL LAPESA, En torno a la española inglesa y el Persiles, en "De la Edad Media a nuestros días", Madrid 1967, pág. 254. 
Así los pormenores de la cautividad y esclavitud de Ricaredo; la conducta caritativa de los trinitarios en Argel, gracias a los cuales tanto Cervantes como Ricaredo recobraron su libertad; la alusión cariñosa a fray Juan Gil a quien sin nombrarle expresamente se atribuye sin duda la redención de Ricaredo, pagada parte al contado parte aplazada, de la misma forma que tuvo lugar la suya; la referencia a la libertad frente a la esclavitud, como el mayor bien del hombre, tan caro a Cervantes; la mención de la insignia de la Orden redentora que los cautivos liberados por ella llevaban en el pecho.

Recuerdos y rasgos autobiográficos son también aquel especial conocimiento que Cervantes revela de las prácticas mercantiles, reminiscencias de sus tiempos de Comisario; la mención del mercader florentino, un tal Roqui, que interviene asimismo como personaje real en la vida de Cervantes; sugerente la determinación de los padres de Isabela de pasarse a las Indias, común refugio de los pobres generosos, que trae a las mientes la suya, también malograda por fortuna para las letras españolas ${ }^{16}$.

3. A Icaza, despierta la atención en la figura imaginada de Ricaredo, su parecido con Cervantes, no sólo en sus aventuras, sino en sus generosos y descabellados empeños; porque el alma de Ricaredo, presentada como espejo de nobleza, valor y cordura, tiene en sus magnánimos arranques muchos puntos de identidad con la de don Quijote, con la cual siempre estuvo en comunicación directa la de Cervantes. La libertad de los apresados de la galera turquesa es algo muy semejante a la libertad de los forzados galeotes ${ }^{17}$.

Se ha dicho que esta Novela materializa el libro de caballerías propuesto por el canónigo en el Quijote. La española inglesa, significativamente una de las más extensas novelas ejemplares, reincorpora elementos característicos de la literatura caballeresca tradicional. Su concepción y estructura novelística se identifican con las características de los libros de caballerías; se constituye en un libro de caballerías moderno ingeniosamente innovado. A las descabelladas aventuras de los libros de caballería que no tienen relación alguna con los hechos verdaderos, Cervantes respondería en La española inglesa con un libro de caballerías ejemplar, ubicando la acción en varios países Europeos y en Argel $^{18}$.

16 G. AMEZUA, loc. cit. pág. 135 s.

17 F. ICAZA, loc. cit. pág. 286.

18 S. ZIMIC, Las novelas ejemplares de Cervantes, Madrid 1996, pág. 144-155. 
En La española inglesa, el heroico caballero andante es la persona de sentimientos nobles, dispuesta a la búsqueda ardua y larga conquista del más sublime Grial que es el amor ${ }^{19}$.

\section{b. Sevilla y el convento de Santa Paula}

1. En las Relaciones contemporáneas del asedio de Cádiz no se menciona un solo caso de rapto de mujeres o niñas. Por ello parece muy dudoso que tenga un fondo histórico el argumento inicial de $\mathrm{La}$ española inglesa que debió más bien su origen sólo a la fértil inventiva de Cervantes ${ }^{20}$.

¿Cabe sin embargo que su conclusión sea un hecho histórico y real, sucedido? Si nos atuviéramos a las palabras mismas de Cervantes, las postreras de su novela, habría que creerlo así.

Categóricamente dice que Isabela en compañía de Ricaredo su marido, aún hoy vive en unas casas que alquilaron frontero del convento de Santa Paula. Y para no dejar duda de la identificación de estas casas, se dice que las compraron de los herederos de un hidalgo burgalés que se llamaba Hernando de Cifuentes; datos precisos, concretos e inconfundibles de la topografía sevillana que Cervantes voluntariamente incluyó en esta novela. El mismo Cervantes vivió a la entrada de la calle donde se ubica el convento de Santa Paula ${ }^{21}{ }^{2}{ }^{\mathrm{P} O} \mathrm{P}-$ día mentir a sabiendas y públicamente en hechos cuya comprobación estaba al alcance de cualquier sevillano contemporáneo suyo?

En consecuencia ¿recogió Cervantes un episodio real? No es ciertamente inverosímil; mas ¿quién puede probarlo?

Ya Fernández Navarrete basándose en este párrafo final tuvo por reales las aventuras de la novela ${ }^{22}$.

2. El convento de Sta. Paula de monjas Jerónimas se fundó a mediados del siglo $\mathrm{XV}$, y se mantiene en la actualidad en pleno casco histórico de Sevilla. Cervantes en La española inglesa cuenta que en el convento de Santa Paula había una monja profesa, sobrina de los padres de Isabela, única y estremada en la voz. Verosimilitud tiene la hipótesis de que la monja hubiese sido persona de carne y hueso, y que

19 Ibidem, pág. 158.

20 G. AMEZUA, loc. cit. pág. 137 ss.

21 JORGE GARCÍA LÓPEZ, Edición y Comentario de las Novelas Ejemplares, Círculo de Lectores, Barcelona 2005, pág. 842.

22 M. FDZ. DE NAVARRETE, loc. cit. pág. 135. 
Cervantes la oyese cantar alguna vez, de modo que el recuerdo de su peregrina garganta pasase a su novela.

El examen de los archivos de Santa Paula ha revelado que profesaron allí entre 1577 y 1597 dos monjas cuyos apellidos sugieren una relación familiar con Cervantes. Poco en efecto significaría el hecho de que en aquel convento hubiesen profesado monjas que en el siglo habían llevado aquel apellido, muy común, en toda Castilla y particularmente en Andalucía, ni que una doña Juana de Cervantes hubiese sido abadesa de Santa Paula; pero son muchas casualidades para no ver en tales nombres algún vínculo con Cervantes que explicaría su afección al monasterio ${ }^{23}$.

Aparece también otra monja Ana de Sto. Domingo que profesó a finales de 1597 hija de Francisco de Cifuentes, al que fácilmente se le identifica como hermano o hijo del citado Hernando de Cifuentes, hidalgo que vendió una casa frontera a Santa Paula donde vivió la pareja protagonista de esta historia, según nos relata Cervantes al final, como dato comprobatorio de su veracidad.

Es posible que Cervantes hubiese tenido relaciones personales con la comunidad de aquel cenobio, que pudo frecuentar también durante sus estancias sevillanas.

En este episodio de La española inglesa hay algo personal, velado y misterioso que se escapa a nuestro conocimiento; pero no hasta el punto que de ello se haya podido forjar el cuento de los amores de Cervantes con la monja cantora, como lo hizo Pascual Madoz, gratuita afirmación que ha tenido no obstante fortuna al haber sido recibido también por otros escritores ${ }^{24}$.

\section{DESARROLLO DE LA NOVELA}

Ya el título debió de sonar sorprendentemente en 1613, por cuanto se trata para aquel tiempo de una verdadera antítesis que revela la conjunción de «española» e «inglesa». Se trataba de una nación hostil y no católica.

Los lectores de la época debieron percibir con perplejidad e intriga semejante título. Se ha calificado la novela de intriga conciliadora ${ }^{25}$.

${ }^{23}$ L. ASTRANA MARIN, loc. cit. vol. VII, pág. 45.

${ }_{24}$ G. AMEZÚA, loc. cit. pág. 139.

25 J. GARCÍA LÓPEZ, Novelas Ejemplares. Crítica, Barcelona 2001, pág. 823. 
Rafael Lapesa, ha intentado explicar esta actitud de Cervantes para Inglaterra por la esperanza que hubo entonces en España de que esta nación volviese pronto al catolicismo ${ }^{26}$.

\section{A. PRIMERA PARTE. LONDRES}

La acción solamente iniciada en Cádiz, se desarrolla principalmente en Londres, para finalizar en Sevilla.

\section{a. La niña raptada en el saqueo de Cádiz}

Entre los despojos que los ingleses llevaron de la ciudad de Cádiz, Clotaldo, un caballero inglés, capitán de una escuadra de navios, llevó a Londres una niña de edad de siete años, poco más o menos; $y$ esto contra la voluntad y sabiduria del conde de Leste, que con gran diligencia hizo buscar la niña para volvérsela a sus padres que ante él se quejaron.

Clotaldo, pudo entregar por riquísimo despojo a su mujer a una hermosa niña. El rapto y traslado oculto de Isabela de Cádiz a Londres constituye una violencia que contraría en seguida los aspectos positivos en que se va desdoblando la Novela.

\section{b. En la casa del católico Clotaldo}

Inglaterra protestante es país enemigo de España. Pero no olvidemos que Clotaldo y todos los de su casa son católicos secretos, de suerte que hasta parece que la presencia de Isabela entre ellos servirá para reafirmarse en su fe.

Tenia Clotaldo un hijo llamado Ricaredo, de edad de doce años, enseñado de sus padres en las verdades de la fe católica. Catalina, la mujer de Clotaldo, noble, cristiana y prudente señora, tomó tanto amor a Isabel que aunque iba aprendiendo la lengua inglesa, no perdía la española.

\section{c. Isabela y Ricaredo}

1. La educación de Isabela es completa excediendo de lo corriente en la época pues aprende a tañer con toda perfección instru-

26 G. AMEZUA, loc. cit. pág. 131 ss. 
mentos musicales y esto acompañándolos con una voz que encantaba cuando cantaba.

Todas estas gracias, adquiridas y puestas sobre la natural suya, poco a poco fueron encendiendo el pecho de Ricaredo.

Pero el amor que se despierta en Ricaredo y sus deseos de ser su esposo tropiezan con una seria dificultad:

Mil veces determinó manifestar su voluntad a sus padres, $y$ otras tantas no aprobó su determinación, porque él sabía que le tenían dedicado para ser esposo de una muy rica y principal doncella escocesa, asimismo secreta cristiana como ellos. Y así, perplejo y pensativo, pasaba una vida tal, que le puso a punto de perderla.

2. El amor a Isabela como una pasión imposible hace enfermar gravemente a Ricaredo que finalmente se le declara, obteniendo su favor, siempre cuando accedan sus padres adoptivos.

- Hermosa Isabela, tu valor, tu mucha virtud y grande hermosura me tienen como me ves. Si me das la palabra de ser mía, yo te la doy, desde luego, como verdadero y católico cristiano, de ser tuyo; que aquel imaginar que con seguridad eres mía será bastante a darme salud.

3. Ricaredo, levantado del lecho, al parecer de sus padres por milagro, no quiso tenerles más tiempo ocultos sus pensamientos.

El joven convence primero a su madre; aquélla habla entonces a Clotaldo y queda dispuesta la boda, anulando con excusas el compromiso casi concluido de casar a Ricaredo con Clisterna una doncella escocesa.

\section{d. En vísperas de la boda}

1. A esta sazón tenía Isabela catorce y Ricaredo veinte años. Cuatro días faltaban para llegarse aquél en el cual los padres de Ricaredo querian que su hijo inclinase el cuello al yugo santo del matrimonio, y no faltaba otra cosa sino hacer a la reina sabidora de aquel concierto; porque, sin su voluntad y consentimiento, entre los de ilustre sangre, no se efectúa casamiento alguno.

2. La narración ha introducido el tema de la autorización real para los matrimonios de los nobles o personas vinculadas a la corona, práctica generalizada en Europa. 
Faltando cuatro días del casamiento surge el primer obstáculo, al llamar la Reina a su presencia a la española, lo que siembra el desconcierto en la familia, que teme se descubra su catolicismo.

Temblaba Ricaredo, casi como adivino de algún mal suceso.

\section{e. En el palacio de la Reina}

1. La acción hace entonces una pausa para detenerse en la detallada descripción del traslado de Isabela a palacio y de su vistosa presentación.

Vistieron a Isabela a la española, con una saya entera de raso verde; collar y cintura de diamantes, y con abanico a modo de las señoras damas españolas. Con este adorno riquísimo y con su gallarda disposición y milagrosa belleza, se mostró aquel día a Londres sobre una hermosa carroza.

2. La queja de la Reina es ocasión para tratar de la licencia matrimonial:

$Y$, volviéndose a Clotaldo, dijo:

-Clotaldo, agravio me habéis hecho en tenerme este tesoro tantos años ha encubierto.

-Señora - respondió Clotaldo- confieso mi culpa: pensaba traerle mejorado, pidiendo licencia a Vuestra Majestad para que Isabela fuese esposa de mi hijo Ricaredo.

-Pero advertid, Clotaldo, —dijo la reina-que sé que sin mi licencia la teníades prometida a vuestro hijo.

-Así es verdad, señora -respondió Clotaldo-, pero fue en confianza que los muchos y relevados servicios que yo y mis pasados tenemos hechos a esta corona.

3. La visión que se tenía sobre las referencias a la Corte inglesa, estaba condicionada por la crítica de Schevill y Bonilla, según la cual Cervantes desconocía por completo el ambiente inglés. Pero modernamente Stagg, después del estudio de varios puntos esenciales, concluye el cercano conocimiento por parte de Cervantes de un período histórico que recuerda los años 1560 y siguientes. Cervantes se dice pudo conocer extremos como lo referido al ambiente de la corte de la Reina Isabel, incluido el conocimiento del castellano de la misma o las aventuras marítimas a las que la reina envía, a partir de 
los relatos orales de los mercaderes ingleses asentados en Cádiz; ello conexiona con el oficio de mercader del padre de Isabela ${ }^{27}$.

\section{f. Al servicio de su Majestad}

1. Salvado el primer obstáculo con la exitosa presentación de Isabela que contenta y admira a la Reina, vuelve a complicarse la acción, por una exigencia de la Reina respecto a aquel matrimonio.

- Ni estará desposado - dijo la reina-con Isabela hasta que por sí mismo lo merezca: él por sí mismo se ha de disponer a servirme y a merecer por si esta prenda, que ya la estimo como si fuese mi hija.

2. Así ingresa Isabela en palacio como dama de la Reina y el joven en la categoría de militar al servicio de su Majestad.

Ricaredo, que se vio quitar la vida en quitarle a Isabela, temblando y con sobresalto, se fue a poner de rodillas ante la reina, quien le dijo:

-Dos navios están para partirse en corso; del uno dellos os hago a vos capitán.

La realización de aquella hazaña para merecer a su dama, se ve complicada con un conflicto moral, pues va dirigida también contra barcos de católicos.

\section{B. SEGUNDA PARTE. AVENTURAS CORSARIAS}

La Novela se alarga en una batalla naval muy del estilo de las de El amante liberal, en cuya descripción hallamos datos que caracterizan la manera de Cervantes que aprovecha una vez más la ocasión para enhebrar episodios de su propia vida militar marinera.

\section{a. Galeras turcas y botín de una nave portuguesa}

1. Cervantes gusta de ofrecer un análisis más profundo de los sentimientos encontrados que pueden darse en el interior de las personas. Lo observamos particularmente al ponerse en manos de Ricaredo la responsabilidad única de las naves a la muerte de apoplejía del otro general.

\footnotetext{
27 J. GARCÍA LÓPEZ, loc. cit. pág. 826.
} 
2. Hay huellas autobiográficas en esta etapa central de la novela, pues se dice que las galeras turcas a las que se enfrentan y abordan eran del pirata Arnaute Mamí, el mismo que mandaba las galeras que atacaron a la Sol donde iba Cervantes cuando fue hecho cautivo.

Pero el dato central lo constituyen los despojos de una nave apresada, que venía de la India cargada de especería, y con tantas perlas y diamantes, que valía más de un millón de oro, y que con tormenta habia arribado a aquella parte, toda destruida; y que aquellas dos galeras, que eran del cosario Arnaúte Mami, el día antes la habian rendido.

3. Concluida la batalla y en posesión Ricaredo del navío apresado junto por las dos galeras turcas conquistadas, se plantea el problema de quedar bien con la reina a la vez que con la propia conciencia. El joven declara que se propone ser liberal con los prisioneros, y la solución para ganar tal fama será dejar en libertad a los españoles, cuando alguien propone pasarlos a cuchillo según llegan a las naves inglesas.

\section{b. Liberados los padres de Isabela}

1. Su decisión de liberar a los prisioneros, recibirá el premio de llevar a Londres a los padres de su amada. La conciencia religiosa de Ricaredo ha superado la prueba ${ }^{28}$. bela.

El español último en trasladarse, se revela como el padre de Isa-

- Por más ventura tuviera, valeroso caballero, le dijo, que me llevaras contigo a Inglaterra, que no que me enviaras a España. Sabrás, señor, que en la pérdida de Cádiz, que sucedió habrá quince años, perdi una hija que los ingleses debieron de llevar a Inglaterra. Tras esta general desgracia, mi mujer y yo, determinamos irnos a las Indias, común refugio de los pobres generosos. $Y$, habiéndonos embarcado en un navio a la salida de Cádiz dieron con el navío estos dos bajeles de cosarios, y nos cautivaron.

2. Con una reacción típica de la novela antigua de intriga, el héroe oculta que conoce a la española inglesa.

Surgen nuevas complicaciones, pero la empresa concluye felizmente.

28 SEVILLA y REY, loc. cit., pág. XXXIV. 
El viento, dándole todas las velas, dentro de nueve días se hallaron a la vista de Londres; $y$, cuando en él, vitoriosos, volvieron, habría treinta que dél faltaban.

\section{TERCERA PARTE: EN TORNO A LA REINA}

El recibimiento y episodio central de la reina, proseguirá luego con la adición de nuevos episodios más dramáticos que los anteriores y que obviamente aparecen como mayores obstáculos: celos apasionados de Arnesto, envenenamiento y pérdida de la belleza de Isabela y peregrinación de Ricaredo.

\section{a. Ricaredo ofrece su presa y solicita su premio}

1. Es ahora cuando se describe por primera vez a Ricaredo: Es alto de estatura, primer dato que debía llamar la atención de un español en el tipo inglés. La detalladísima pintura de las armas del militar, se corresponde con el atuendo de Isabela al ser presentada en la corte. El amante es Marte en el brío militar y los adornos.

Saltó en el esquife, armado de todas armas, ricas y resplandecientes, el valeroso Ricaredo, que a pie, se fue a palacio, donde ya la reina, puesta a unos corredores, estaba esperando. Estaba con la reina, con las otras damas, Isabela.

2. Siguen dos largos discursos, uno del héroe ofreciendo a la Reina su victoria junto con las riquezas capturadas y reclamandole el premio ofrecido, y otro de la Reina ponderando a Isabela. Ricaredo después de dar cuenta de la pareja española que ha traído con él, concluye su discurso, refiriéndose al tesoro y a su suspirado premio:

Pasa de un millón de oro el valor de la especeria y otras mercancías de perlas y diamantes que en ella vienen. A ninguna cosa se ha tocado, yo lo mandé guardar, para Vuestra Majestad, que con una joya sola que se me dé, quedaré en deuda; la cual joya ya Vuestra Majestad me la tiene prometida, que es a mi buena Isabela.

La Reina responde:

-Levantaos, Ricaredo, y creedme que si por precio os hubiera de dar a Isabela, no la pudiérades pagar con lo que trae esa nave. Dóyosla porque os la prometí, y porque ella es digna de vos y vos lo 
sois della. Idos a descansar y venidme a ver mañana, que quiero más particularmente oír vuestras hazañas; $y$ traedme esos dos que decís que de su voluntad han querido venir a verme.

\section{b. Anagnórisis en clave moderna}

1. Con el reencuentro de padres e hija concluye verdaderamente el núcleo de la novela, en la medida en que el autor ha resuelto con ello todos los elementos de la introducción.

El día que siguió fue Ricaredo a palacio, llevando consigo al padre y madre de Isabela, diciéndoles que la reina quería verlos.

-Aquella mujer y aquel hombre que allí están, —señalando a los padres de Isabela-, encarecidamente me pidieron los trujese conmigo. Ellos son de Cádiz.

2. El reconocimiento o anagnórisis se opera en el presentimiento antes de que exista verdadera consciencia.

Lo mismo ocurre en La gitanilla y en La fuerza de la sangre, pero en ninguno de estos casos se describe tan compleja y dramáticamente la adivinación instintiva, como en La española inglesa.

Al saber que los españoles que ha traído consigo Ricaredo son de Cádiz, se comienzan a despertar en la memoria de Isabela que los mira atentamente, confusas noticias y recuerdos lejanos. Ellos a su vez pusieron los ojos en Isabela y también su corazón presagió el bien al que no podían dar crédito.

Todo un proceso psicológico, descrito con sumaria precisión, subraya la creciente tensión del reconocimiento instintivo: Isabela suda y se compone el peinado varias veces. Señalados los signos exteriores de su desconcierto el novelista no nos revela lo que está pensando la protagonista, pero observa la atención de Ricaredo que es el único que conoce la verdad, a los efectos y movimientos de aquellas tres perplejas y confusas almas.

3. Cervantes extrema los preludios instintivos de la anagnórisis con la referencia a la voz o memoria auditiva. El modo es muy acorde con los cánones de la novela griega según el modelo clásico, no faltando tampoco las señales corporales, y por último los desmayos, pero el proceso aparece aquí tratado con moderna profundidad psicológica.

En esto, deseaba Isabela que hablase la que pensaba ser su madre: quizá los oídos la sacarían de la duda. La reina dijo a Isabela que en lengua española dijese a aquella mujer y a aquel hombre. 
Todo esto preguntó Isabela a su madre, la cual, sin responderle palabra, desatentadamente y medio tropezando, se llegó a Isabela y, sin mirar a respecto, temores ni miramientos cortesanos, alzó la mano a la oreja derecha de Isabela, y descubrió un lunar negro que allí tenía. $Y$, viendo claramente ser Isabela su hija, abrazándose con ella, dio una gran voz y se cayó desmayada en los brazos de Isabela.

\section{c. El conde Arnesto desafía a Ricaredo}

1. Las complicaciones que pronto se presentan no provienen de los triunfos de Ricaredo, sino de la extraordinaria belleza de Isabela; Cervantes describe las calamidades que se preparan en los cuatro días fijados por la reina como plazo para la boda, la misma cifra de los que faltaban para la nupcias cuando la española es llamada a palacio.

2. El desarrollo del nuevo obstáculo requiere la introducción de los nuevos personajes: el conde a Arnesto y su madre, camarera mayor de la Reina.

Es, pues, el caso que la camarera mayor de la reina, a cuyo cargo estaba Isabela, tenía un hijo de edad de veinte y dos años, llamado el conde Arnesto. Este Amesto, pues, se enamoró de Isabela encendidamente. Y, puesto que la repugnancia y los desdenes suelen hacer desistir, en Arnesto obraron lo contrario los muchos y conocidos desdenes que le dio Isabela.

El contumaz rival, al conocer de la inminencia de la boda de Isabela, utiliza el valimiento de su madre ante la Reina. Le suplicó suspendiese el desposorio de Isabela por otros dos días. Y así, después contó a la reina los amores de su hijo.

3. Como nada consigue, el conde Arnesto se ve arrastrado por su despecho: Reta al perplejo Ricaredo, desafío al que éste responde como caballero.

No faltó quien lo fue a contar a la reina, la cual mandó al capitán de su guarda que fuese a prender al conde.

La pronta intervención pospone el desafío para más adelante, como prolongación de los obstáculos a la felicidad de la pareja.

\section{d. La madre de Arnesto envenena a Isabela}

1. Quedó la camarera tan desconsolada que determinó de hacer una de las mayores crueldades que pudo caber jamás y fue su determinación matar con tósigo a Isabela. 
Lo relativo al crimen de la camarera está desarrollado con gran rapidez: los síntomas del envenenamiento, la intervención de las otras damas acusando a la culpable, la de los médicos, y por fin cómo la española con la ayuda de la ciencia y de Dios se salvó.

2. La camarera había acudido al envenenamiento, recurso que hace aún más melodramáticos los polvos de unicornio, que los médicos de la Reina aplicarán en cantidad a la española, junto con otros antídotos.

La reacción de la Reina ante su camarera mayor no se hace esperar.

Mandó la reina prender a su camarera y encerrarla en un aposento estrecho de palacio.

\section{e. Isabela se desposa con fealdad mostruosa}

1. Finalmente, Isabela no perdió la vida, que el quedar con ella la naturaleza lo conmutó en dejarla sin cejas, pestañas y sin cabello; el rostro hinchado, la tez perdida.

El amor de Ricaredo supera la nueva prueba, confirmando así su pureza y generosidad.

Recuérdese que la misma prueba se ofrece a Auristela afeada por envenenamiento por celos en Persiles y Sigismunda.

2. Ricaredo además se ve acosado en ese mismo tiempo por la llegada de la bella Clisterna llamada de propósito por sus padres a la vista de la fealdad de Isabela.

Obligado por tanto a elegir en el momento de mayor intensidad de toda la novela, entre la hermosura física y la belleza únicamente espiritual, el héroe no lo duda; elige a su amada Isabela, proclamando la pureza absoluta de su amor.

$Y$, dándole ella la derecha y asiéndola él con la suya, prosiguió diciendo:

- Por la fe católica juro y por el verdadero Dios que nos está oyendo, te prometo, joh Isabela, mitad de mi alma!, de ser tu esposo, y lo soy desde luego si tú quieres levantarme a la alteza de ser tuyo.

Besóla Ricaredo en el rostro feo, no habiendo tenido jamás atrevimiento de llegarse a él cuando hermoso. 
Ricaredo le hace confesión de amor con promesa de matrimonio, según la institución católica de los esponsales. Ricaredo viajará luego a Roma a asegurar su conciencia, peregrinación y confesión que le prepara a unirse a Isabela ${ }^{29}$.

3. Mas el enamoramiento de Ricaredo choca muy pronto con la realidad en derredor suyo: Sus padres han decidido llevar a cabo el anterior proyecto de alianza matrimonial con la doncella escocesa. Ricaredo en conmovedora escena promete a la española reunirse con ella en el plazo de dos años.

La respuesta de Isabela es una da decisión extrema de amor: No sólo le aguardaría dos años, sino todos los de su vida hasta estar enterada que él no la tenía; porque en el punto que esto supiese sería el mismo de su muerte. El autor ha disipado antes de la declaración los temores del lector anunciando que la fealdad de la española dura sólo dos meses.

\section{f. Marcha y espera de Isabela y sus padres a España}

1. Ricaredo desposado ya con Isabela con la mutua promesa de matrimonio, dilata la celebración del matrimonio que sus padres proponían de inmediato, con su peregrinación previa a Roma significativamente para la aseguración de su conciencia.

Clotaldo, aquel mismo día fue a pedir licencia a la reina, para enviar a Isabela y a sus padres a España.

2. No se olvida Cervantes de la camarera, informándonos que sin llevar el asunto por la vía legal, se la condenó a una indemnización de 10.000 escudos en favor de Isabela y a no servir más en su oficio, en tanto que se desterraba a su hijo cosa que facilitará luego su venganza.

La partida de Isabela y sus padres para España constituye un detallado episodio con abundantes notas de carácter esencialmente económico. Se describe con minucia el dinero que recibieron los españoles en Londres; cómo lo cobrarían en España por intermedio de un mercader; las dificultades del tráfico entre Inglaterra y España; y por fin, cómo se ocupó la reina del viaje mismo de sus protegidos, cosa nada fácil ya que la nave debía recabar en Francia para poder hacer escala en Cádiz, a título de partir de Francia y no de Inglaterra. 126.

29 J. CASALDUERO, Sentido y forma de las Novelas ejemplares, Madrid 1974, pág. 


\section{CUARTA PARTE. EN SEVILLA}

Como es fácil advertir, cuando Cervantes abandona Londres, deja también los tópicos descriptivos. En su Andalucía se encuentra en su casa; pero adviértase que ahora no es Cádiz que sólo se menciona de paso y en correspondencia forzada con la primera parte, sino Sevilla, ciudad cuyas calles, casas, conventos y quienes los habitan, les son particularmente familiares.

\section{a. De Cádiz a Sevilla}

1. Aquella noche se hizo el bajel a la vela; $y$, habiendo con próspero viento tocado en Francia y tomado en ella los recados necesarios para poder entrar en España, de alli a treinta días entró por la barra de Cádiz, donde se desembarcaron Isabela y sus padres.

Advirtamos que las relaciones hostiles entre España e Inglaterra continúan, como lo muestra la forzosa escala en Francia, para arribar al puerto de Cádiz a donde es forzoso el regreso para conectar con el punto de partida.

El tránsito de Cádiz a Sevilla se disculpa por las transacciones dinerarias, pues la populosa ciudad es el emplazamiento idóneo como centro destacado del Comercio para Europa y América.

2. Poco más de un mes estuvieron en Cádiz y luego se fueron a Sevilla por ver si salía cierta la paga de los diez mil ducados que, librados sobre el mercader francés, traian. Dos dias después de llegar a Sevilla le buscaron, y le hallaron y le dieron la carta del mercader francés de la ciudad de Londres. El la reconoció, y dijo que hasta que de París le viniesen las letras y carta de aviso no podía dar el dinero; pero que por momentos aguardaba el aviso.

Llegados Isabela y sus padres a Sevilla donde esperan cobrar sus letras de crédito, se acumulan nuevos datos mercantiles. El mercader que debe entregarles los 10.000 escudos tiene que esperar por la letra de París.

\section{b. Junto al convento de la monja de voz única}

1. Al centrarse el relato en Sevilla en torno al convento de Santa Paula, hace Cervantes a este propósito curiosas precisiones: sobre una prima monja de voz extraordinaria que moraba en ese monas- 
terio y sobre la casa que alquilaron los padres de Isabela cerca de dicho convento.

Todo ello apunta a un conocimiento personal del convento de Santa Paula por Cervantes y quizá a la existencia y relación con la monja cantora. La maravillosa voz de la prima monja se relaciona con la maestría de Isabela en el arte musical que conocemos; son en fin aspectos de un mismo interés que valora y diferencia la acabada educación de la protagonista y su entorno.

2. Los padres de Isabela alquilaron una casa principal, frontero de Santa Paula, por ocasión que estaba monja en aquel santo monasterio una sobrina suya, única y estremada en la voz, y asi por tenerla cerca como por haber dicho Isabela a Ricaredo que, si viniese a buscarla, la hallaría en Sevilla y le diría su casa su prima la monja de Santa Paula, y que para conocella no había menester más de preguntar por la monja que tenía la mejor voz en el monasterio, porque estas señas no se le podian olvidar.

3. Isabela en la espera a su prometido se comporta con recato extremo sin salir de su casa sino para ir a misa. Pasan los meses mientras Isabela se mantiene en su enamorada esperanza a pesar de los deseos que su belleza despertaba en su alrededor. Cervantes no olvida la descripción de los pretendientes y celestinas que solicitan a la retraída joven; ello nos muestra que no estamos en una ciudad abstracta como Londres, desconocida por Cervantes, sino en Sevilla población bullidora y viva.

4. No se pierde ni se desconecta la relación familiar con Londres a través de la singular vía mercantil. La muerte de Isabel de Inglaterra acaecida en 1603, se menciona indirectamente cuando la Reina no responde a las cartas de Isabela; pero las noticias de Ricaredo se siguen a través del contacto con sus padres.

\section{c. La falsa noticia de la muerte de Ricaredo}

1. Isabela que espera en Sevilla a su amante siente correr el tiempo sin recibir noticias. Cervantes nos retrata el estado de ánimo de la joven con tan viva expresión de amor como no se halla por cierto en ninguna otra heroína de las Novelas. Es como el presentimiento de una separación mortal falsamente anunciada.

Año y medio era ya pasado cuando la esperanza propincua de los dos años por Ricaredo prometidos, comenzó con más ahínco que has- 
ta alli a fatigar el corazón de Isabela. Y cuando ya le parecía que su esposo llegaba, llegó a sus manos una carta de la señora Catalina, fecha en Londres cincuenta días habí; venía en lengua inglesa, que así decía:

"Hija de mi alma: bien conociste a Guillarte, el paje de Ricaredo. Éste se fue con él al viaje. Pues este mismo Guillarte, a cabo de diez y seis meses que no habiamos sabido de mi hijo, entró ayer por nuestra puerta con nuevas que el conde Arnesto habia muerto a traición en Francia a Ricaredo».

2. Acabada de leer la carta, se levantó de un estrado donde estaba sentada y se entró en un oratorio; y, hincándose de rodillas ante la imagen de un devoto crucifijo, hizo voto de ser monja, pues lo podía ser teniéndose por viuda.

Isabela templa su dolor con la plegaria y consuela a sus padres. Éstos le ruegan que espere a que expire el plazo convenido.

\section{d. El voto de entrar monja}

1. Pasóse el término de los dos años y llegóse el día de tomar el hábito, cuya nueva se extendió por la ciudad. Hicieron a Isabela uno de los más honrados acompañamientos que en semejantes actos se habia visto en Sevilla. Hallóse en él el asistente, y el provisor de la Iglesia y vicario del arzobispo, con todas las señoras y señores de título que había en la ciudad. $Y$, como es costumbre de las doncellas que van a tomar el hábito ir lo posible galanas y bien compuestas. Con este adorno y con su gallardía, salió Isabela de su casa a pie, que el estar tan cerca del monasterio escusó los coches y carrozas.

2. La localización de la casa de los padres de Isabela, se explica ahora como un recurso para que vaya Isabela a pié desde su casa hasta el convento de Santa Paula. La escena es similar a aquella otra de la ida de la protagonista desde la casa de Clotaldo hasta el palacio de la Reina, pero ahora sin carroza para ser mejor vista, luciendo por cierto el mismo vestido de española; si la muchedumbre se apiñaba en las calles de Londres para ver a la bella española, en Sevilla se agolpa para contemplar a la inglesa.

\section{e. Detenida a la puerta del convento}

1. En la puerta del monasterio y en el momento exacto en que se cumple el término fijado, se hace presente también la otra parte, 
Ricaredo que aparece desconocido, trasmutado con hábito de excautivo que contrasta con el galano atuendo de su prometida.

$Y$ el que más solícito se mostró, y tanto que muchos echaron de ver en ello, fue un hombre vestido en hábito de los que vienen rescatados de cautivos, con una insignia de la Trinidad en el pecho, en señal que han sido rescatados por la limosna de sus redemptores.

2. Ricaredo en atuendo de cautivo con cabello rubio y tez colorada que lo señalan como extranjero, interrumpe aquel cortejo.

Este cautivo, pues, al tiempo que ya Isabela tenía un pie dentro de la portería del convento, donde habian salido a recibirla, como es uso, la priora y las monjas con la cruz, a grandes voces dijo:

_iDetente, Isabela, detente! Que mientras yo fuere vivo no puedes tú ser religiosa.

$Y$, asiéndola de la mano, le dijo:

- ¿Conócesme, Isabela? Mira que yo soy Ricaredo, tu esposo.

Isabela abrazándose con el cautivo, le dijo:

-Vos, sin duda, señor mío, sois aquel que sólo podrá impedir mi cristiana determinación. Vos, señor, sois sin duda la mitad de mi alma, pues sois mi verdadero esposo.

2. Va a quedar sin efecto a la puerta del monasterio, la determinación de Isabela de profesar como religiosa.

Es la misma Isabela la que se expresa claramente, y muestra la obligación que considera tiene de cumplir la promesa dada a Ricaredo:

- Mas, pues Dios con tan justo impedimento muestra querer otra cosa, ni podemos ni conviene que por mi parte se impida.

Todas estas razones oyeron los circunstantes, y el asistente, y vicario, y provisor del arzobispo.

Finalmente, la gente más principal, con el asistente y aquellos dos señores eclesiásticos, volvieron a acompañar a Isabela a su casa, dejando a las monjas tristes, confusas.

Para mostrar la verdad de la trama relatada, se encuentra entre los presentes el mercader contra quien va dirigida una letra de Ricaredo.

$Y$ luego, en diciendo esto, sacó de una caja de lata los recaudos que decía, y se los puso en manos del provisor, que los vio junto con el señor asistente. 

chos:

Y por último para confirmarlo se apunta la redacción de los he-

Lo mismo hicieron los dos señores eclesiásticos, y rogaron a Isabela que pusiese toda aquella historia por escrito, para que la leyese su señor el arzobispo; y ella lo prometió.

\section{E. EXCURSUS: RICAREDO RELATA SUS PERIPECIAS}

Cuenta Ricaredo episodios que ignorábamos de su peregrinación a Roma con una nueva serie de obstáculos, recopilados en su relato. La narración de Ricaredo trata de ser avalada por detalles verídicos, como son las letras dinerarias semejantes a las de los padres de Isabela, el precio del rescate, y la generosidad de los frailes redentores.

\section{a. Peregrinación a Roma y adhesión católica}

1. Atravesando por Francia, llegué a Roma, donde se alegró mi alma y se fortaleció mi fe. Besé los pies al Sumo Pontífice, confesé mis pecados con el mayor penitenciero; absolvióme dellos.

2. Adviértase que el purificar y confirmar su fe católica mueve a Ricaredo a peregrinar a Roma, lo mismo que ocurre a Persiles y Sigismunda al final de la novela. Con ello alcanzada la plenitud espiritual, fortalecida su fe, recuperada la belleza de Isabela, el matrimonio cristiano sería el premio definitivo de tantas pruebas trabajos y sinsabores $^{30}$.

\section{b. Arnesto intenta dar muerte a Ricaredo}

1. Prosigue el relato con la más sangrienta de las pruebas, que por otra parte nos recuerda las muertes «aparentes" que como sabemos no faltan en la novela bizantina:

-Llegué con Guillarte, mi criado, a un lugar que se llama Aquapendente, y en una hostería o posada, donde me apeé, hallé al conde Arnesto, mi mortal enemigo, disfrazado y encubierto. Creí sin duda que no me había conocido; mas, poco después de la media noche, me despertaron, cuatro pistoletes que, dispararon con-

30 SEVILLA Y REY, loc. cit. pág. XXXV. 
tra mí el conde y sus criados; y, dejándome por muerto, teniendo ya a punto los caballos, se fueron.

2. El criado creyéndole asesinado huye despavorido.

Subieron los de la hostería y halláronme atravesado con cuatro balas pero de ninguna fue mortal la herida. Curáronme, y no estuve para ponerme en camino en dos meses; al cabo de los cuales vine a Génova, donde no hallé otro pasaje, sino en dos faluas.

\section{c. Cautivado y llevado a Argel}

1. Una vez más la novela va a reproducir no sólo recuerdos sino experiencias vivas de Cervantes, aunque lo haga de una forma sumaria, para no repetir escenas que ya había narrado en la novela del Cautivo y en sus obras teatrales de cautiverio.

El relato de Ricaredo abunda en sugerencias autobiográficas Cervantinas: el lugar donde fue capturada su falua, un paraje que llaman las Tres Marías, que es en la costa de Francia, su cautiverio en Argel y su rescate por padres trinitarios.

Trujéronnos a Argel, donde hallé que estaban rescatando los padres de la Santísima Trinidad. Hablélos, díjeles quién era, y, movidos de caridad, me rescataron en esta forma: dieron por mí trecientos ducados, los ciento luego y los docientos cuando volviese el bajel de la limosna a rescatar al padre de la redempción, que se quedaba en Argel empeñado en cuatro mil ducados, que habia gastado más de los que traía.

2. Cervantes muestra su experiencia en los rescates de la cautividad suministrando detalles de los modos y sobre todo de los precios de cautivos, lo mismo que se había mostrado al respecto en El amante liberal. Tampoco escatima sus alabanzas a los frailes redentores, que dan su libertad por la ajena, y se quedan cautivos por rescatar los cautivos.

Casi un año se tardó en volver la nave de la limosna; y lo que en este año me pasó, a poderlo contar ahora, fuera otra nueva historia.

\section{d. Redimido llega a Valencia y Sevilla}

Finalmente, el padre redemptor vino a España conmigo y con otros cincuenta cristianos rescatados. En Valencia hicimos la procesión general con las insignias de su libertad, que son estos habiticos. 
De nuevo hay que subrayar el carácter autobiográfico de esta escena con el emotivo recuerdo de su llegada a la patria vuelto del cautiverio, escenas que encontramos en diversos lugares de la obra de Cervantes, pero de modo especial en la Novela del Capitán cautivo. villa.

El relato de Ricaredo termina trasladándose puntualmente a Se-

Hoy llegué a esta ciudad, con tanto deseo de ver a Isabela, mi esposa, que, sin detenerme a otra cosa, pregunté por este monasterio, donde me habian de dar nuevas de mi esposa.

\section{F. EPÍLOGO}

Concluye la Novela con una especie de epílogo en el que explica el novelista sus propósitos, para terminar finalmente afirmando explícitamente la ejemplaridad.

\section{a. La trascripción de los hechos}

Se ha advertido que el método de los «modelos vivos» ha afectado a la consideración de esta novela de forma peculiar. Al final del relato dos eclesiásticos han rogado que esta historia se ponga por escrito para que la lea el Arzobispo. El paralelismo con la gestación del Manuscrito de Porras de la Cámara no podía ser más evidente. Se llega a darse por sentado que Cervantes estaba dando noticia de la transmisión manuscrita privada de sus novelas en la Sevilla de fines del siglo XVI; una idea en modo alguno descabellada, si bien no ha dejado de ser discutida. Astrana Marin recoge el dato que considera equivocado, de que el arzobispo de que se habla en la novela fuese Niño de Guevara, y uno de los dos eclesiásticos Porras de la Cámara; se basa en su datación de la novela, según la cual cuando Cervantes la compone el Cardenal Niño de Guevara había muerto ya y era arzobispo de Sevilla De Castro y Quiñónes que le había sucedido a finales de $1610^{31}$.

\section{b. La boda y la ejemplaridad moral}

Claro está que la Novela ha de terminar en boda, que es la meta de un largo camino y el premio a la virtud, esfuerzo y amor.

31 L. ASTRANA MARÍN, loc. cit. pág. 43, n. 1. 
Ellos suplicaron al asistente honrase sus bodas, que de alli a ocho días pensaban hacerlas. Holgó de hacerlo así el asistente, y, de allí a ocho días, acompañado de los más principales de la ciudad, se halló en ellas.

Por estos rodeos y por estas circunstancias, Isabela favorecida del cielo y ayudada de sus muchas virtudes, a despecho de tantos inconvenientes, halló marido tan principal como Ricaredo, en cuya compañia se piensa que aún hoy vive en las casas que alquilaron frontero de Santa Paula, que después las compraron de los herederos de un hidalgo burgalés que se llamaba Hernando de Cifuentes.

Esta novela nos podría enseñar cuánto puede la virtud, y cuánto la hermosura, pues son bastantes juntas, y cada una de por si, a enamorar aun hasta los mismos enemigos; y de cómo sabe el cielo sacar, de las mayores adversidades nuestras, nuestros mayores provechos.

Cervantes explicita la lección moral de la Novela, cosa que ocurre pocas veces; adviértase sin embargo que es la enseñanza que se puede sacar en general de cualquier novela bizantina clásica.

\section{COMENTARIO E INTERPRETACION}

\section{A. ¿DOBLE REDACCIÓN? DESCONEXIÓN Y NÚCLEO CENTRAL}

\section{La desconexión del suceso histórico:}

Se ha señalado que el asalto de Cádiz y el rapto, sugieren la cuestión de una probable doble redacción de la novela. Cervantes que se detiene en la vida de Isabela en Londres y luego en Sevilla, parece haberse olvidado en el decurso de la historia del rapto de Isabela en Cádiz, momento inicial.

Hay por otra parte datos como el que los padres de Ricaredo críen a Isabela como a una hija, y conviviendo con ellos y con Ricaredo, éste pueda enamorarse de ella sin el tabú del incesto; esta situación en La ilustre fregona, Cervantes la resuelve con el desdoblamiento de los galanes, haciendo que el posible enamorado sea el único de los dos que puede ser su esposo.

Por otra parte del hecho de que además los padres de Isabela en el resto de la novela no vivan en Cádiz sino en Sevilla, parece comprobar una probable doble redacción de la novela que intenta cerrar a satisfacción la antitética datación del relato. 
2. El rapto se superpone al núcleo central

El núcleo central y primitivo estaría constituido por la estancia de una española en la Corte inglesa, lo que parece llevarnos a fechas cercanas a 1560; ese relato terminaría con el viaje de Ricaredo directamente a Sevilla.

Sobre esta estructura preliminar se superpuso una segunda redacción, al parecer más larga, donde Cervantes introdujo el asalto a Cádiz con el rapto que coloca a Isabela en un medio extraño y precisa el reecuentro o anagnórisis y añade la peregrinación de Ricaredo a Roma y su cautividad final en Argel ${ }^{32}$.

\section{B. PARALELISMO CON OTRAS NOVELAS}

\section{a. «El amante liberal»}

1. Para Avalle-Arce, Cervantes en La española inglesa, cuarta novela de la colección, retoma alguno de los temas de El amante liberal, la segunda de Las Novelas Ejemplares. Pero las variantes y enriquecimientos que afectan a dichos temas en su nuevo tratamiento novelístico, son espectacular y literalmente ejemplares.

La española inglesa se abre con un saqueo de Cádiz por los ingleses en 1596, hecho tan histórico como la captura de Nicosia por los turcos, comienzo de El amante liberal.

El mar y las aventuras marítimas, tienen lugar prominente en la acción de El amante liberal en las luchas representadas entre sicilianos y turcos que narran saqueos y capturas; todo esto en el Mediterráneo oriental, en el triángulo de Sicilia, Chipre y el norte de Africa.

Las peripecias novelísticas introducen también en La española inglesa el tema marítimo, combates navales y guerras, esta vez encarnadas entre católicos españoles e ingleses protestantes; la acción también tiene lugar en un triángulo aproximado, ahora Cádiz Londres y Sevilla, pero en el otro extremo de Europa ${ }^{33}$.

Por lo pronto en El amante liberal el tema del amor es central, pero durante la mayor parte de la novela el amor de Ricardo es rechazado por Leonisa, si bien todo culmina con el matrimonio cristiano de ambos.

32 J. GARCÍA LÓPEZ, Edición y Comentario de las Novelas Ejemplares, loc. cit. pág. 842.

33 J. B.AVALLE-ARCE, loc. cit. pág. 7. 
En La española inglesa después de un número determinado de pruebas a que se ve sometido el amor de la pareja de prometidos, todo se corona con el matrimonio cristiano. El paralelismo basado en hacer del matrimonio la meta de la virtud resalta en el encuentro final entre Ricaredo e Isabela.

2. Cervantes en El amante liberal presenta un medio extranjero, que debía servir de fondo decorativo, con su arabesco sensual, dando más realce al amor puro cristiano: tiendas turcas, costumbres exóticas, los personajes de los bajaes, del cadí y su mujer. La función de fondo de contraste de este medio extranjero es evidente; el ambiente turco no sólo daba una nota sensual sino que estaba tratado con una gran riqueza de situaciones pintorescas y de colorido. En el medio extraño de El amante liberal, lengua, tipo, también vestimentas, son sin embargo un medio; las mujeres turcas, nos dice Cervantes, no se cubren la cara ante los hombres cristianos quizá porque no los consideran como hombres. La sensualidad turca es sumamente cómica; es como un mundo con el cual no tenemos nada que ver.

En La española inglesa también tenemos un medio extranjero, pero no tanto; un protestante, es un cristiano, de lejos es muy parecido a un católico. Para un no cristiano la diferencia entre un protestante y un católico es mínima o inexistente. Esta cercanía y proximidad exigen una labor de presentación: un cuidado, una sutileza en el trazo, que sin embargo permita con todo rigor captar el hecho diferencial. Tenemos pues delicada pero decididamente presentado un medio extranjero. No se insiste en ningún trazo abultadamente pintoresco; basta la calidad de extranjero.

Inglaterra pertenece a la misma civilización, y en una parte oculta a la misma religión; Ricaredo y su familia son católicos en secreto $^{34}$.

3. No hay que esforzarse para ver que cada punto de parecido entre ambas Novelas está representado en un mundo de diferencias. Cervantes nunca volvió al mismo tema con intenciones de repetirlo y repetirse, sino muy al contrario, con el propósito de iluminarlo en un nuevo juego de cambiantes perspectivas.

Aquí en La española inglesa, Cervantes se aparta de la superficialidad de aventuras marítimas, combates navales, capturas etc. por su hábil intensificación del tema espiritual. Por otra parte, la profunda espiritualidad de La española inglesa, la novela más religiosa y de más

34 J. CASALDUERO, loc. cit. pág. 121 ss. 
clara afirmación católica de todo el volumen, la separa de El amante liberal mucho más sensual. Y en consecuencia nos presenta el tema palpable de la preocupación absorbente de Cervantes por la religión al entrar en los postreros años de su vida: La espiritualización del argumento apunta ya con claridad meridiana al Persiles y Sigismunda, el libro póstumo de Cervantes ${ }^{35}$.

4. La española inglesa sigue de cerca los cauces de la novela bizantina, con su característica de historia amorosa de una pareja fiel y honesta, que se ve sometida a una serie de viajes, aventuras marítimas y terrestres, separaciones y reencuentros, anagnórisis, peligros, incertidumbres, superación de diversos obstáculos y final feliz.

No obstante las diferencias entre las dos Novelas son asimismo obvias. Hay además elementos estructurales de primer orden que son antitéticos:

El amante comienza con el relato en primera persona que hace el héroe cuando está separado de su amada, para una vez reunido con la misma proseguir en tercera persona hasta su final feliz. La espanola inglesa, justo al contrario, se inicia en tercera persona con el conocimiento amoroso del inglés y la gaditana y prosigue así casi hasta el final; hasta que tras la separación, reaparece el héroe y entonces al revés que en la otra novela, Ricaredo narra en primera persona sus peripecias. Unamos a ello que el protagonista de una se llama Ricardo y el de la otra Ricaredo, con lo que nos daremos cuenta cabal de las interconexiones textuales de semejanza y desemejanza que se establecen entre los dos relatos ejemplares ${ }^{36}$.

\section{b. «Persiles y Sigismunda»}

1. Los paralelos entre La española inglesa y Los trabajos de Persiles y Sigismunda se dan a todo nivel. Debido a estas características se puede decir que La española inglesa es una miniatura del Persiles o bien si miramos las cosas desde la otra orilla, el Persiles es una superfetación de La española inglesa ${ }^{37}$.

Finalmente, conviene recordar que en La española inglesa Cervantes con gesto insólito, en un acto final apunta a la ejemplaridad allí contenida: esta novela nos podría enseñar cuánto puede la virtud y

35 J. B.AVALLE-ARCE, loc. cit. pág. 8.

36 SEVILLA Y REY, loc. cit. pág. XXV.

37 J. B. AVALLE-ARCE, loc. cit. pág. 9. 
cuánto la hermosura. La verdad del caso es perfectamente aplicable asimismo a Persiles con lo que se terminan de estrechar los lazos que unen a ambas novelas.

2. Las conexiones entre ambas Novelas son muy abundantes y no sólo por su carácter común genérico bizantino con todo lo que implica, ni por los espacios semejantes a veces por las cercanías en los mares ingleses en relación directa con España.

La unión de ambas novelas se produce sobre todo por la confluencia de amor y religión, ya que el intenso y casto amor de los protagonistas de ambas novelas es similar en su espiritualidad.

Persiles se enamora tan intensamente de Sigismunda que enferma al igual que le acaece a Ricaredo con Isabela.

Los respectivos padres tienen que incumplir un primer compromiso matrimonial previo.

Un envenenamiento afea horriblemente a Isabela, un hechizo convierte en un monstruo del fealdad a Sigismunda; pero el amor espiritual puro de Ricaredo por la una y de Persiles por la otra, se mantiene incólume y vence sobre tan adversa circunstancia, pues va más allá de la belleza física en ambos casos, aunque las dos recuperan después su impar hermosura.

La misma fe católica mueve a Persiles y Sigismunda hacia Roma, que a Ricaredo, con el deseo común de todos ellos de reafirmar su credo, que se ve sometido a otras presiones en sus lugares de origen. La peregrinación espiritual a Roma es así solidaria en las dos novelas de su triunfo final, encarnado en el matrimonio cristiano que consuma ambas peripecias narrativas.

No obstante la religiosidad de ambas narraciones hace que el matrimonio contienda con el monasterio y el amor humano entre en liza con el amor divino: Isabela va a profesar cuando la aparición de Ricaredo lo impide concluyendo con la boda feliz de los enamorados. Sigismunda ya en Roma aún convaleciente, sufre una crisis religiosa y está a punto de ingresar también en un monasterio, aunque felizmente no lo hace. Sin embargo se encuentra en el Persiles la otra historia. la de don Manuel de Sousa Coutiño, que ya conocemos, que guarda todavía más semejanza con el caso de La española inglesa aunque su resultado sea opuesto, pues Leonora a diferencia de Isabela se decide finalmente por ser esposa de Cristo ${ }^{38}$.

${ }^{38}$ SEVILLA y REY, loc. cit. pág. XXVI. 
4. Para Rafael Lapesa el árbol escueto de La española inglesa aparece rodeado de apretadas frondas en el Persiles. Hay que preguntarse si la multitud de aventuras, personajes y temas ha surgido en el Persiles como desarrollo del sencillo asunto de la novela ejemplar, o si éste ha sido aprovechado para que sirviera de apoyo e imprimiera sentido a una fantasía independientemente creada. Más probable parece la segunda solución.

5. Cabe concluir diciendo que nuestro relato es un momento intermedio en relación al Persiles, una suerte de "concentración" de Cervantes para darle al Persiles su talla definitiva; un «segundo momento" en su proceso de redacción. Un primer momento serían los libros I y II del Persiles redactados al parecer entre 1599 y 1605; el segundo sería La española inglesa, aceptando la fecha de Lapesa de 1609 a 1611. Un tercer momento serían los libros III y IV del Persiles, llenos del mismo ambiente literario que La española inglesa. Así en el gozne de la Novela ejemplar se articulan la acentuación del tema religioso y su concomitante el perfeccionamiento espiritual tan notable en la segunda mitad del Persiles.

Rafael Lapesa, emparenta a ambas obras a través de la transformación o purificación espiritual de los dos héroes, Persiles y Ricaredo ${ }^{39}$.

En un aspecto más amplio, la temática de ambas novelas se identifica de la siguiente manera: la peregrinación como peripecia, el amor como móvil y la religión como aglutinante. La proximidad al Persiles se refuerza por el uso en esta novela de la figura del peregri$\mathrm{no}^{40}$. La "peregrinatio amoris» es también "peregrinatio vitae» ${ }^{41}$.

\section{c. Una historia sefardí y su posible relación}

1. Una pista sefardí debida a García Gómez ha vuelto a replantear en 1991 la cuestión del origen histórico del relato ${ }^{42}$.

La Española inglesa corre muy paralela a la historia de Maria Núñez tal como nos la cuenta el poeta Miguel Leví de Barrios (1635-1701) ${ }^{43}$.

39 RAFAEL LAPESA En torno a La española inglesa y el Persiles, en «Homenaje a Cervantes» Valencia 1950, pág. 305.

40 J. GARCÍA LÓPEZ, loc. cit. pág. 828.

${ }^{41}$ Cfr. E. VIVÓ DE UNDABARRENA, Persiles el peregrino andante la obra póstuma cervantina (Peregrinación, matrimonio y derecho) en "Boletín de la Facultad de Derecho», UNED, 2000, n. 15, pág. 131.

${ }^{42}$ A. M. GARCÍA GÓMEZ, Una historia sefardi como posible fuente de Cervantes, en Actas del II Coloquio Internacional de la Asociación de Cervantistas, 1991, pág. 621.

43 MIGUEL LEVÍ DE BARRIOS, Triunfo del gobierno popular, Amsterdam 1683. 
Maria Núñez se embarca con su familia para Holanda huyendo de las persecuciones contra los judíos. El texto nos muestra un importante lugar paralelo:

Tomaron los ingleses que tenian guerra contra España a los propuestos navegantes, y un duque inglés enamorado de la rara hermosura de María Núñez, la solicitó con tan amante extremo que la reina Isabela de Inglaterra informada de su amor, ordenó que la trajesen y dejando libre al navio por su respecto, con benignas promesas la llevó en su carroza para mostrar a los de Londres un prodigio de belleza.

Poco después en 1598, cuando se reúne toda la familia en Amsterdam, se casa la heroica María Núñez con Manuel López Homen.

2. El núcleo de la historia como se ve, corre muy cercano del relato cervantino. Es una historia fechable hacia el año 1597 y que podría haber llegado a la Península por vía sefardí y a Cervantes por conducto oral.

El paralelismo con el relato de Cervantes se intensifica en su final, en tanto que es posible documentar la presencia del matrimonio de María Núñez y Manuel López en Sevilla antes de 1612, tal como se desprende de un documento notarial conservado en Ámsterdam y fechado a finales de ese año, donde se da cuenta además que Manuel López Homen después de estar un tiempo en Lisboa, se había trasladado a Sevilla, donde debió estar hasta 1619. Por ello es verosímil que la historia fuese escuchada por Cervantes, pudiendo haberla oído poco después de 1602; ello nos adelantaría la fecha de su escritura a cualquiera de las que se dan como más probables para la composición novelesca ${ }^{44}$.

3. Sin embargo el mismo García Gómez se plantea una objeción elemental sobre esta influencia. Necesario es tener en cuenta que el referido texto se publica en 1683 , fecha tardía que obliga a considerar la posibilidad de que sea la novela de Cervantes la que hubiera dado origen al episodio de la bella María Núñez y no viceversa. La hipótesis de la prioridad del texto cervantino estará sin duda condicionada por el grado de veracidad histórica que se tenga del texto de Barros en el cual se alude a unos hechos ocurridos antes de la composición de La española inglesa ${ }^{45}$.

44 J. GARCÍA LÓPEZ, loc. cit. pág. 825.

45 A. M. GARCÍA GÓMEZ, loc. cit. pág. 622. 


\section{A. SIGNIFICADO DE LA NARRACIÓN}

\section{a. El amor une a España e Inglaterra}

1. A un español de principios del siglo XVII, el amor entre una española y un inglés debía parecerle poco menos que imposible. Ya el título debió sonar original y sorprendente a los lectores en 1613, por cuanto que se trata de una verdadera antítesis ${ }^{46}$. Nuestro autor además había dejado clara su postura española pocos años antes, en 1588 con dos canciones patrióticas a La Armada que fue contra Inglaterra, rotundamente antibritánicas y exaltadamente españolas.

2. Bien es cierto que el primer fervor nacional de Cervantes se había mitigado y lejos de toda exaltación patriótica, se había transformado en un tanto desengañado. La primera prueba de este desencanto crítico fue muy significativa, precisamente un soneto centrado en el saqueo inglés de Cádiz de 1596, esto es, el mismo hecho histórico, que sirve de punto de partida para nuestra Novela. El trágico suceso impresionó vivamente a nuestro novelista, que se hallaba entonces en Andalucía; la mirada irónica y desencantada de su soneto no ocultan el dolor por España que tal hecho le produjo.

3. Cervantes fue capaz de distanciarse literariamente de sus sentimientos patrióticos y crear una obra literaria, La española inglesa que superase el enfrentamiento tradicional anglo español.

Las circunstancias habían cambiado tras la muerte de la reina Isabel en 1603: en 1605 se firmó un tratado de paz, había un embajador inglés en España que además hablaba castellano, se creía no sólo en las buenas relaciones entre España e Inglaterra, sino incluso en la posibilidad de que el catolicismo acabaría por triunfar en Inglaterra durante el reinado de Jacobo I.

No hay duda de que la nueva situación debió de atemperar el orgullo español de Cervantes. Ninguna hostilidad aparece en su narración; presentándose siempre a la Reina con gran decoro.

El reto literario de esta Novela radicaba precisamente, en hacer que el amor más puro uniera a una española y un inglés, en el reinado de Isabel I, en la época más difícil, y partiendo además del ataque inglés a Cádiz de 1596 y de la esclavización de una española. Dotar de verosimilitud a tan pasmoso evento fue la meta que se propuso y que logró.

46 J. GARCÍA LÓPEZ, Edición y Comentario de las Novelas Ejemplares, loc. cit. pág. 217. 
Por eso la estructura tan equilibrada, para que reinara la armonía entre los enamorados de las dos nacionalidades y el inglés no predominara sobre la española, ni ésta sobre aquél; para que la ponderación y la concordia presidieran el amor de Isabela y Ricaredo ${ }^{47}$. La Novela podría haberse titulado igualmente «El inglés español».

Cervantes con el matrimonio del inglés Ricaredo y de la española Isabela, dramatiza su fervorosa aspiración a la unión fraternal de todos los pueblos.

4. El estudio de la cronología de La española inglesa cuestión que podría parecer a los ojos de algunos baladí e intrascendente, tiene sin embargo positiva importancia. La vida no pasa en balde para nadie: la acción del tiempo cambia en su transcurso la ideología, transforma los caracteres, altera la visión de los hombres y de las cosas del escritor; estas mudanzas espirituales las reflejará en sus obras.

Punto digno de análisis es el de la tolerancia que demuestra Cervantes al enjuiciar a la reina Isabel de Inglaterra y a los personajes de su séquito. Fresco todavía el fracaso de la Invencible y el recuerdo de la bárbara crueldad de los ingleses para con los infelices náufragos de ella arrojados a su costa, esta actitud de Cervantes contrasta sobremanera. En sus dos canciones Sobre la Armada que fue contra Inglaterra Cervantes se irrita ásperamente ante los latrocinios, asaltos y violencias del pérfido inglés, y exhorta Felipe II para que le ponga el justo yugo que merece.

Esta actitud hostil de Cervantes a Inglaterra, cambia radicalmente años después al escribir La española inglesa. La habitual tolerancia cervantina se extrema más en esta novela. En ella la pintura que hace de la Reina Isabel, está en absoluta contradicción con el sentir de su tiempo. Cervantes apartándose de esta casi unánime opinión de sus contemporáneos, demuestra ser un hombre superior, capaz de dominar sus sentimientos.

\section{a. De la belleza corpórea a la del espíritu}

1. En El amante liberal el hombre tenía que luchar con la sensualidad más elemental, debía dominar sus pasiones para cantar la verdadera libertad; en cambio, La española inglesa presentando una escala parecida, pone todo el acento en el descubrimiento de la ver-

47 SEVILLA y REY, loc. cit. pág. XXXI. 
dadera belleza del alma. La fealdad de Isabela nos hace pasar de la belleza corpórea a la belleza de espíritu. Los ojos del hombre capaces únicamente de admirar la belleza física, transforman todo en fealdad, y entonces insatisfechos, van en busca del espíritu, del alma; pero al sentirse iluminados por la gracia, entonces puede volver a contemplar el mundo en toda su belleza ${ }^{48}$.

2. La lección de la novela es que en La española inglesa por primera vez se expresa clara y deliberadamente dentro de la colección la enseñanza que puede extraerse de cada una de las Novelas:

Esta novela nos podría enseñar cuánto puede la virtud y cuánto la hermosura pues son bastante juntas y cada una de por sí a enamorar aún hasta los mismos enemigos, y de cómo sabe el cielo sacar de las mayores adversidades nuestros mayores provechos.

Pero junto aquel amor puro está el copioso contrapunto que proporcionan las descripciones al detalle de los mecanismos cambistas de la época. El amor de los héroes tiene los pies en la tierra.

\section{c. La afirmación católica}

1. El sentido principal de la novela cervantina, en consecuencia es la clara afirmación católica, desde la convicción plena de que los valores espirituales humanos del catolicismo alcanza la mayor pureza del sentimiento amoroso y permiten su universalización.

La peripecia del héroe comienza en la corte inglesa y concluye en Roma. Tal paralelismo antitético, por descontado no es inocente. Muestra las orillas del camino de perfección que transita Ricaredo de la mano de Isabela: del medio acatólico a la cátedra de San Pedro.

2. Los trabajos de la peregrinación amorosa, eje común de la acción novelesca, hacen posible mostrar la idealización del sentimiento amoroso, que trae consigo la exhalación de la pureza y la pasión del alma. La valoración de las virtudes morales desemboca en un culto de la virtud interior y la pureza. La peregrinación en esta novela pone de relieve todo el simbolismo que adquirió durante el segundo Renacimiento, como búsqueda de la felicidad a través de la experiencia de regeneración que ésta supone. Ricaredo representa de manera incluso más clara que Andrés o Ricardo, el paradigma del

48 J. CASALDUERO, loc. cit. pág. 128. 
hombre barroco, el ideal del caballero cristiano, el arquetipo y el compendio de todas las cualidades estoicas ${ }^{49}$.

\section{CONCLUSIONES}

\section{A. CONSIDERACIONES MATRIMONIALES}

Esta Novela como otras, tienen el clásico colofón de la boda, pero aquí no es tanto un modo de concluir un relato amoroso, sino sobre todo la terminación de un camino, el del noviazgo tiempo de preparación al matrimonio en el que Cervantes pone toda su atención, convirtiéndose lo mismo que en las precedentes en argumento de la Novela. Diríamos que el punto de mira de las tres primeras Novelas Ejemplares no es la boda sino el noviazgo.

En esta Novela se aborda además un tema específico y peculiar, el del rapto matrimonial, que una norma del Concilio de Trento había puesto de relieve.

\section{a. El matrimonio premio final}

El matrimonio cristiano es la clave y objetivo final de toda la Novela, que es presentada como un camino que lleva a tal meta final, como premio de un constante esfuerzo. En ello sigue las líneas paralelas de las otras dos novelas que le preceden, La gitanilla y El amante liberal.

Los obstáculos de La española inglesa están dispuestos alternativamente para ambos protagonistas, que al superarlos, los amantes demuestren que se merecen el uno al otro. Superándolos, como dice Bataillón, la felicidad que viene después, no es otra que el matrimonio cristiano.

De la celebración de la boda apenas se nos dice otra cosa que celebrada a los ochos días del suceso final, estuvieron presentes en ella, el Asistente y personas principales de la ciudad.

No hay duda que se trata de una boda celebrada en la normativa tridentina, si bien con la dispensa de alguna de las proclamas, dado el plazo de ocho días que se señala.

49 M. J. GARCÍA DEL CAMPO, Elementos bizantinos en tres novelas ejemplares de Cervantes, en Actas del II coloquio internacional de la Asociación de cervantistas, Barcelona 1991, pág. 617. 


\section{b. El noviazgo como peregrinación amorosa}

1. En las tres novelas, La gitanilla, El amante liberal y La española inglesa, no es la boda sino el período que precede, que en la primera y en la última es formalmente un verdadero noviazgo, lo que ocupa la atención del autor y de la Novela, considerado como un precioso tiempo de preparación y de merecimiento, que en la otra Novela, $E l$ amante liberal es un período de conquista y de transformación.

En los tres casos es la castidad de los novios lo que Cervantes presenta con singular aprecio, resaltando particularmente la virginidad que la protagonista sometida a serias dificultades en alguno de ellos como es en El amante liberal.

En La española inglesa, lo que se pone de relieve es la fidelidad y sobre todo la transformación del atractivo físico que produce la belleza de la novia, en atractivo espiritual, alcanzado por el aprecio de las virtudes de la misma.

2. La Reina Isabel pone en marcha la primera prueba: Ricaredo sale en corso para demostrar con su valor que es digno de Isabela, lo que da al mismo tiempo lugar a que ella le corresponda esperándole.

Superado este primero, se presentan otros obstáculos: Ricaredo ha vivido en una ambiente protestante y tiene que demostrar su fidelidad católica.

Aparece entonces el recurso a los amores entrecruzados, pues un conde Arnesto se enamora de Isabela. El rechazo de ésta produce una doble venganza: el desafío de Arnesto y la acción de la madre contra la protagonista intentando envenenarla. Cervantes utiliza esta vez la magia que aparece tanto en los relatos de corte bizantino al que nuestro autor no es dado a recurrir.

Clisterna vuelve a la escena, pero el héroe está decidido por Isabela pues ha conseguido descubrir la importancia de la belleza espiritual. Se dan plazo de dos años en que Ricaredo marcha a Roma tiempo en que vivirá todavía desventuras, mientras Isabela regresa a Sevilla donde le esperará. La peregrinación de Ricaredo ha servido para que el héroe refuerce sus virtudes católicas. España su destino era la representación máxima del catolicismo.

Habiendo demostrado los dos jóvenes recíprocamente su fe, tanto católica como amorosa, su premio final es el matrimonio ${ }^{50}$.

50 Ibidem, pág. 818. 


\section{c. La libertad para contraer matrimonio}

1. La novela bordea un tema que el Concilio de Trento había abordado entre los abusos que en la época amenazaban al matrimonio cristiano, estableciendo sus normas para proteger la libertad imprescindible en la constitución del mismo. Curiosa y extrañamente la Novela comienza con la narración de un delito execrable como el del rapto de una niña, situación que gravita durante toda ella.

Pero forzoso es preguntarse si se dio en el caso la situación de impedimento que pudiese afectar al matrimonio de Ricaredo e Isabela.

Necesario es referirse previamente a la norma que entonces regía este supuesto.

2. La posibilidad del matrimonio entre raptor y la raptada, si ésta y sus padres posteriormente consentían en el mismo, había sido práctica legalizada por Inocencio III que tuvo por válido y aun por lícito el matrimonio con la raptada, «si la anterior negativa pasaba luego a consentimiento ${ }^{51}$.

Y como sea que tal disposición fue incluida en el «Liber Extra» de Gregorio IX, según el Derecho de las Decretales el rapto no constituía propiamente un impedimento distinto del capítulo de «vis et metus", sino que se consideraba solamente como una especie de él. Hacía tiempo que se había desvanecido en consecuencia la figura y peculiar naturaleza jurídica del rapto del Derecho Romano que había empezado a perfilarse en el Derecho canónico particular.

En el Concilio de Trento no faltaron voces que reclamaban la vuelta al antiguo rigor. El Concilio trató el rapto, situando el punto de mira en la libertad de la celebración del matrimonio. La anterior ley que prohibía el matrimonio entre el raptor y la raptada abrogada la concesión de Inocencio III, se convirtió en irritante, con lo que quedaba restablecido de nuevo el impedimento de rapto:

No puede haber válido matrimonio entre el raptor y la raptada mientras ésta permanezca en poder de aquél; más si la raptada separada del raptor y constituida en lugar seguro y libre, quiere tenerle por marido, téngale éste por mujer ${ }^{2}$.

3. No hay duda que estamos en presencia de un delito de rapto, aun cuando no cometido por Ricaredo sin por su padre. Aunque

51 INOCENCIO III en la Decretal «Accedens. Rapta».
52 CONCILIO DE TRENTO, Ses. XXIV, cap. VI. 
este es perpetrado cuando Isabela es impúber, ésta es retenida durante su edad núbil.

Resulta curioso el cuidado que Cervantes tiene para soslayar este impedimento, en todas sus circunstancias. Obsérvese sobre todo como retrasa la celebración del matrimonio hasta que ciertamente Isabela esta fuera del lugar en que la había constituido y retenido el raptor, Londres y su propia casa, de tal modo que la boda se celebra no sólo cuando ha sido restituida a sus padres, sino cuando se halla en su propia tierra de España.

\section{d. La promesa de matrimonio y voto de entrar en religión}

1. Cervantes tiene un episodio en Persiles y Sigismunda paralelo al que concluye con esta Novela, pero paradójicamente contrapuesto. Es el relato de Manuel Sousa Coutiño que Cervantes ha elaborado inspirado en la verdadera historia de éste. El personaje soldado de noble familia de Lisboa, que enamorado de Leonora Pereira, hija única la había pedido por esposa, es obligado a esperar por dos años. De regreso de Affica cuando se cumple el día del plazo, le avisan los padres que la entrega de Leonora va a tener lugar en la iglesia de un monasterio. Acude el militar portugués al templo, y describe el encuentro con Leonor que se presenta vestida de raso blanco, acompañada de las religiosas. Y es allí donde ésta le comunica que no puede contraer con él, porque ya es casada, pues se ha entregado a Jesucristo $^{53}$.

Este caso y el de La española inglesa, hacen a Cervantes plantearse la cuestión de la confrontación entre el cumplimiento de la promesa de matrimonio y el del voto de consagrarse a Dios.

La disyuntiva entre bodas místicas y bodas humanas, con la solución tradicional y su resultado más extremoso, aparece encarnada en el relato del Persiles de Manuel Sousa Coutiño, que tiene como consecuencia la muerte del desdichado.

Con original y distinta solución sitúa el caso Cervantes en La española inglesa, donde Ricaredo reaparece cuando su prometida está a punto de profesar en religión, devolviéndose Isabela al amor humano en el umbral del convento. Igual solución se da en el mismo Persiles para la pareja de sus protagonistas, presentándola Cervantes como la correcta en contraposición al desenlace dramático acos-

${ }^{53}$ CERVANTES, Persiles $y$ Sigismunda, lib. I c. 10. 
tumbrado, exponiéndola en toda su amplitud, y siguiendo los propios Persiles y Sigismunda la línea iniciada por Ricaredo e Isabela.

El voto de entrar en religión que rompía una promesa de matrimonio preocupó a Cervantes y a muchas personas, incluidos autores espirituales de su tiempo como Fray Luis de Granada y San Juan de Ávila, dada la grave repercusión o trágico resultado en el otro miembro de la pareja en desacuerdo con tal cambio de propósito.

En el Persiles Cervantes defiende la tesis de que no cabe unirse a Dios con amor de perfección y con ello hacer daño mortal a una pobre criatura de Dios con la que ya se estaba unido por promesa de matrimonio.

En La española inglesa Cervantes lo tenía más fácil pues tal voto se había hecho por creer erróneamente desaparecida la promesa con la muerte de la otra parte ${ }^{54}$.

\section{B. CONSIDERACIONES JURÍDICO MERCANTILES}

Siempre ha llamado la atención tan extensas, insistentes y pormenorizadas referencias a las transacciones comerciales, con ocasión de los viajes de Isabela y Ricaredo a España.

\section{a. Profusas referencias bancarias}

1. En el curso de la novela si bien prima el ambiente espiritual, no es éste el único. Se puede decir que en la segunda mitad menudean las referencias al comercio, a la vida bancaria, a la economía en general como si fueran ecos de la vida de Comisario de Cervantes.

2. Las abundantes referencias bancarios se acompañan de minuciosos detalles mercantiles que se inician con ocasión de la partida de Isabela de la corte y se repiten a su llegada a Sevilla.

La reina llamó a un mercader rico, que habitaba en Londres y era francés, el cual tenía correspondencia en Francia, Italia y España, al cual entregó los diez mil escudos, y le pidió cédulas para que se los entregasen al padre de Isabela en Sevilla o en otra plaza de España. El mercader, descontados sus intereses y ganancias, dijo a la reina que las daria ciertas y seguras para Sevilla, sobre otro mercader francés, su co-

${ }^{54}$ E. VIVÓ DE UNDABARRENA, loc. cit. pág. 131. 
rrespondiente, en esta forma: que él escribiría a París para que allí se hiciesen las cédulas por otro correspondiente suyo, a causa que rezasen las fechas de Francia y no de Inglaterra, por el contrabando de la comunicación de los dos reinos, y que bastaba llevar una letra de aviso suya sin fecha, con sus contraseñas, para que luego diese el dinero el mercader de Sevilla, que ya estaría avisado del de París.

Las datos bancarios prosiguen en el viaje de Ricaredo a Roma, proporcionándonos circunstancias concretas y hasta nombres, como es el caso del cambio romano que le libró 1600 ducados Roqui mercader Florentino residente en Sevilla.

Hecho esto, de dos mil escudos que tenía en oro, di los mil y seiscientos a un cambio, que me los libró en esta ciudad sobre un tal Roqui florentín. Con los cuatrocientos que me quedaron, con intención de venir a España, me partí para Génova, donde había tenido nuevas que estaban dos galeras de aquella señoría de partida para España.

En el reencuentro de la pareja se halla casualmente el mercader a quien Ricaredo muestra su pagaré:

Ordenó el cielo que se hallase presente a todo esto el mercader Florentín, sobre quien venía la cédula de los mil y seiscientos ducados, el cual pidió que le mostrasen la cédula; y, mostrándosela, la reconoció y la aceptó para luego, porque él muchos meses habia que tenía aviso desta partida.

\section{b. Razón de tan abundantes datos}

1. A todos los enterados de las hostilidades entre España e Inglaterra en la época en que se sitúa la acción, les resultaría totalmente increíble un viaje marítimo comercial directo entre los dos países, cuando menos sin complicados arreglos bancarios tramitados con otros países. Es pues en consideración a estas expectativas particulares de sus lectores por lo que Cervantes considera oportuno detenerse en todos esos detalles. Significativamente en ninguna otra obra cervantina se dan descripciones extensas de este tipo, pues en ninguna de ellas el ambiente político de fondo las requiere ${ }^{55}$.

2. La compleja lentitud de la tramitación mercantil, unida al plazo inexorable de los años de espera pactados para el matrimonio, aumenta el dramatismo del emplazamiento temporal e intensifica la an-

55 S. ZIMIC, loc. cit. pág. 155 s. 
gustiosa sensación que produce el tardo paso de los días sin que reaparezca Ricaredo.

La percepción literaria del tiempo como una fuerza poderosa, que incluso se puede equiparar al destino, a la Providencia, es una de las mayores aportaciones de esta novela.

Los Románticos españoles a partir de Larra no echaron en saco roto desde luego el hallazgo cervantino. Éstos a diferencia de nuestro novelista hacen que los protagonistas de sus novelas lleguen siempre tarde, por unos segundos. Pero la angustiosa dimensión temporal de La española inglesa plasma aunque felizmente, la acuciante incertidumbre del sentimiento del tiempo; se constituye por tanto en una de las más sólidas aportaciones de la literatura española, a causa de su modernidad y mantiene la vigencia actual de un texto narrativo injustamente desdeñado ${ }^{56}$.

3. Es obvio que Cervantes nunca pretendió escribir una novela mística a lo que ni el propio Persiles apunta. Así pues cuando sus crecientes preocupaciones religiosas le llevan a idear las diversas pugnas espirituales de La española inglesa, procede con cuidadoso tino al dotar a la acción de un denso contenido de espiritualidad.

Así en la segunda mitad de la novela antes de que se dé la solución final del matrimonio cristiano, Cervantes procede a compensar, a equilibrar ese denso ambiente, con una multiplicidad de detalles y referencias a la vida económica, y muy en particular a la vida bancaria. Y si en esta parte de la Novela prima el ambiente espiritual, no es su único tema. A lo largo del relato Cervantes contrapuntea la relación amorosa con toda suerte de explicaciones sobre los mecanismos de pago de la época (cédulas, letras de cambio, cartas de aviso etc. $)^{57}$. Se recuerdan los tiempos de Comisario de Cervantes y el oficio de mercader del padre de Isabela.

Ello se debe al hecho fundamental de que para Cervantes el matrimonio cristiano es el triunfo de la ortodoxia humana, como explicó Marcel Bataillon; ${ }^{58}$ y la ortodoxia humana está anclada en el «aquí y ahora», lo que queda claramente insinuado en los datos económicos que circundan el matrimonio cristiano de Ricaredo e Isabela ${ }^{59}$.

56 SEVILLA Y REY, loc. cit. pág. XXXVI. 846.

57 J. GARCÍA LÓPEZ, Edición y Comentario de las Novelas Ejemplares, loc. cit. pág.

58 M. BATAILLON, Cervantes y el matrimonio cristiano. Varia lección de clásicos españoles, Madrid 1964, pág. 238

59 J. B. AVALLE-ARCE, loc. cit. pág. 15. 